\title{
Determinants of Student Social Inclusion in Malaysian Universities
}

\author{
Sepideh Sedaghatnia ${ }^{1}$, Amir Ghahramanpouri ${ }^{1}$, Hasanuddin Lamit² \\ ${ }^{1}$ Department of Architecture, Faculty of Built Environment, \\ ${ }^{2}$ Centre for Study of Built Environment in the Malay World (KALAM), \\ Universiti Teknologi Malaysia, Malaysia \\ sepideh_ft10@yahoo.com
}

\begin{abstract}
This study aims to identify main factors affecting students' social inclusion in universities. A selfadministered questionnaire has been administered to a stratified sample of 360 students from three research universities of Malaysia. Through conducting factor analysis, ten constructs including legibility, social relation, hostel quality, facilities, extracurricular activities, accessibility, safety, comfort, academic services, and transportation were identified. The findings of the study can be used by university administrators as a guide for better understanding of students' needs and allocate resources effectively in the campus environment.
\end{abstract}

Keywords: Social inclusion, Campus, Student, Exploratory factor analysis

eISSN 2398-4295 @ 2018. The Authors. Published for AMER ABRA cE-Bs by e-International Publishing House, Ltd., UK. This is an open-access article under the CC BY-NC-ND license (http://creativecommons.org/licenses/bync-nd/4.0/). Peer-review under responsibility of AMER (Association of Malaysian Environment-Behaviour Researchers), ABRA (Association of Behavioural Researchers on Asians) and cE-Bs (Centre for EnvironmentBehaviour Studies), Faculty of Architecture, Planning \& Surveying, Universiti Teknologi MARA, Malaysia.

DOI: http://dx.doi.org/10.21834/ajbes.v3i12.123 


\subsection{Introduction}

Higher education is becoming increasingly globalized and internationalized (Robson, 2011). Due to a large and diverse population of students, universities have played a vital role in providing a conducive learning environment that not only attracts students, but also engages them effectively within the universities (Crosling et al., 2008). One of the ways institutions reaches this goal is meeting students' needs by measuring their satisfaction (Zhai, 2012). Student satisfaction includes the students' subjective experiences during the college years and perceptions of the educational experiences value (Astin, 1993). Moreover, it has a positive relationship to the desired outcome such as academic performance, positive word of mouth (WOM), retention and loyalty (Arambewela \& Hall, 2009).

Accordingly, numerous empirical studies have investigated different factors influencing student satisfaction from three perspectives. The first approach is highlighted by studies that examine service quality models in higher education institutions. Scholars argued that university facilities and services have an impact on student satisfaction (e.g. Joseph and Joseph, 1997; Price et al., 2003; Douglas et al., 2006; Petruzzellis et al., 2006; Gruber et al., 2010). The second approach indicates previous studies, which address student quality of life in universities (Sirgy et al., 2007; Arsalan \& Akkas, 2013). The third approach is the one that measure student engagement by the National Survey of Student Engagement (NSSE). This instrument measures student involvement in meaningful educational activities (Astin, 1984; Pascarella \& Terenzini, 2005; Marti, 2008; Kahu et al., 2013). None of the aforementioned approaches examines student attitudes towards campus physical characteristics while the literature suggests that the physical aspects stimulate students' engagement and enhance their academic performance (Strange \& Banning, 2000).

Although researchers have conducted many studies on student satisfaction, they are mainly focused on a single aspect of higher education institutions. The number of studies that simultaneously investigate multiple dimensions of satisfaction is limited. Therefore, this study fills this gap by utilizing Social Inclusion Theory. Social inclusion, as a multi-dimensional concept, involves interconnecting factors to enable individuals to gain the opportunities and services to participate fully in society (Levitas et al., 2007). Therefore, this study aims to identify the significant factors affecting student social inclusion in Malaysian universities.

\subsection{Literature Review}

\section{Definition of social inclusion and exclusion}

During the last decade, promoting social inclusion and combating social exclusion have emerged as important social policy issues. There is little difference between these two concepts (Kenyon, 2011). In fact, social exclusion is based on an implicit vision of inclusion (Hodgson \& Turner, 2003) and both enhance urban social sustainability (Ghahramanpouri et al., 2013).

Social exclusion is defined in origin and content with other concepts such as poverty, social relations, social sustainability and quality of life (Room, 1995; Atkinson, 2000; Church et al., 2000; Sedaghatnia et al., 2013; Ghahramanpouri et al., 2015). 
Room (1995) distinguished exclusion as (a) multidimensional concept; (b) dynamic processes; (c) recognition of the importance of context; (d) relational issues such as inadequate social participation and lack of social integration; and (e) disconnection from society. According to Silver (1994), "social exclusion is a rupturing of the social bond and is a process of declining participation, access, and solidarity. At the societal level, it reflects inadequate social cohesion. At the individual level, it refers to the incapacity to participate in normatively expected social activities and to build meaningful social relations" (Silver, 1994). More recently, Levitas et al. (2007) defined, "social exclusion as a complex and multidimensional process. It involves the lack of resources, rights, goods and services, and the inability to participate in normal relationships and activities, available to the majority of people in society, whether in economic, social, cultural, or political arenas. It affects both the quality of life of individuals and the equity and cohesion of society as a whole" (Levitas et al., 2007).

\section{Student inclusion and campus environment}

Over the past decades, many researchers have offered theories describing the interaction between students and their campus environments. The most comprehensive framework is Strange and Banning's (2000) model of campus design attributes, which promotes student success. They used Maslow's (1968) model and proposed a hierarchy of learning environment purposes in which the safety and inclusion of students positioned at first, followed by promoting student involvement, and then circumstances that encourage full membership in a learning community (Strange \& Banning, 2000). This model is a useful tool in helping designers and planners to prioritize different levels of student needs (Strange, 2003).

Regarding the hierarchy, the first level is identified by two distinct aspects of safety and inclusion. The experiencing sense of belonging on campus and being safe are fundamentals for the pursuit of opportunities leading to learning, growth, and student development. As a second-tier condition in this hierarchy, involvement engages students in meaningful activities and the extent to which they can integrate with the social environment of the educational institution (Astin, 1984). Although security, inclusion, and involvement fulfill the first-tier and second-tier conditions, the most influential settings are communal. A community shares a common location and purpose in which students experience a complete sense of membership in a setting and create a positive human learning environment (Strange, 2003).

\subsection{Methodology}

\section{Survey instrument}

An instrument was developed through reviewing past studies, utilizing the existing instruments and conducting focus groups. The review has covered various domains including social inclusion and exclusion (Levitas et al., 2007; Scutella et al., 2010), student satisfaction (e.g. Price et al., 2003; Jiewanto et al., 2012); student engagement (Astin, 1984; Tinto 1993, Pascarella \& Terenzini, 2005); quality of college life (Sirgy et al., 2007) and campus design and planning (Strange \& Banning, 2000). 
Following the item development stage, validity and reliability of the instrument were investigated through expert interviews, cognitive interviews, and pilot test. A draft of the completed instrument was reviewed and commented by a panel of experts to address the content validity. Based on their suggestions, minor wording modifications and adaptation were made for few items. Subsequently, cognitive interviews with three undergraduate and three postgraduate students were conducted to ensure the constructs would obtain valid information. They were asked to read the revised version of the instrument and to comment on any ambiguous or unclear statements. Their feedback provided perceptive suggestions on the readability and wording. Finally, a pilot test was carried out to a representative group of students $(\mathrm{N}=30)$ to examine clarity, usability, and appropriateness of the items and to determine the initial internal consistency of items.

The final questionnaire was comprised of 40 -items addressing safety, accessibility, legibility, comfort, extracurricular activities, social relation, hostel quality, facilities, academic services, and transportation. The participants were asked to rate their level of satisfaction with these aspects based on a five-point Likert scale ranging from 1 (very dissatisfied) to 5 (very satisfied).

\section{Participants and procedures}

During November and December 2013, the questionnaire forms were distributed in three Malaysian research universities, namely Universiti Teknologi Malaysia (UTM), Universiti Sains Malaysia (USM) and Universiti Malaya (UM). The data was collected using a stratified random sampling of 360 students in multiple academic disciplines. A total 312 usable responses, which is an acceptable sample for factor analysis, remained for analysis.

\section{Data analysis}

The statistical methods used in this study include descriptive statistics and factor analysis with Principal Component Analysis (PCA) by using the statistical package for Social Sciences SPSS 16. Internal consistency of the items is measured through Cronbach's alpha method. Considering 0.70 or above as a target level, Cronbach's alpha coefficient was computed for the entire instrument as well as for each factor generated from the principle component analysis (Pallant, 2010).

\subsection{Results and Discussions}

Among a total of 312 respondents, 101 students (32.4\%) were male, and $211(67.6 \%)$ were female. The majority of the participants (51.9\%) were between 19 to 24 years of age, followed by those (37.5\%) in the 25 to 34 year's age group. In terms of ethnicity, the majority $(62.8 \%)$ were Malay while the rest were comprised of Chinese (13.5\%), Indians (3.8\%) and other ethnic groups (19.9\%). Respondents from undergraduate $(51 \%)$ and postgraduate $(49 \%)$ level have almost similar distribution.

A principal component analysis using varimax rotation was done to determine the proper dimensions of student social inclusion in the campus environment. To ensure the appropriateness of the data for factor analysis, a series of statistical assumptions were met. 
Barlett's test of sphericity $(p=0.000)$ and the Kaiser-Meyor Olkin measure of sampling adequacy $(\mathrm{KMO}=0.903)$ all indicated that the data set was very appropriate for conducting factor analysis. The factors extraction decisions were guided by the following rules: (a) factors with eigenvalues greater than 1.0 (Kaiser Criterion), (b) examination of the scree plot, (c) The amount of factor loadings greater than 0.40 , (d) a minimum of three items should be included in each factor (Pallant, 2010). The factor analysis initially generated eleven factors. Based on the stated criteria, only ten factors, explaining $62.567 \%$ of the total variance were accepted. Therefore, results revealed that legibility, social relation, hostel quality, facilities, extracurricular activities, accessibility, safety, comfort, academic services and transportation, affect student inclusion at university campuses.

On the other hand, results of internal consistency tests show that the reliability coefficient for the entire instrument was $\alpha=0.95$. In addition, Cronbach's alpha for all factors varied from 0.82 to 0.87 (higher than the acceptable rate of 0.7 ). Therefore, it is concluded that the scale has a high level of reliability. Factor loading, percent of the total variance, and Cronbach's alpha coefficients (a) explained by each factor are summarized in Table 1.

These findings support previous studies on student satisfaction by other researchers who have emphasized social integration and the physical facilities of university (Astin, 1984; Balyer \& Gunduz, 2012; Najib et al., 2012). Price et al. (2003) indicated that the university facilities such as library and computing facilities, classrooms, laboratory equipment, recreational amenities, health services, accommodation, and public transport services are influential in student university choice. Astin (1993) also pointed out the importance of social integration including student interaction with faculty members and peers and involvement in extracurricular activities in student growth and development.

Furthermore, this study added empirical support to the existing literature and identified physical quality as an important dimension of an inclusive campus environment. This finding supports the contention of earlier studies, (Dober, 1992; Strange \& Banning 2000) that physical attributes are among the most important factors influencing student engagement and personal development. Many researchers have agreed upon the importance of the physical elements of campus such as wayfinding, safety, comfort, accessibility, campus layout (Marcus and Francis, 1998; Abu-Ghazzeh, 1999; Salama, 2011; Abd-Razak et al., 2011).

It is notable to declare that in this study, legibility is perceived by students as the most important dimension of inclusion. This construct highlights the fact that wayfinding, sufficient landmarks, easily recognizable buildings are perceived to be the most significant variables influencing student inclusion in the campus environment. Legibility refers to how the environment can be functioned and whether people can understand the environment immediately and explore it without getting lost (Weisman, 1981). It is a crucial component of the physical environment, affecting a feeling of belonging and security especially to persons viewing the campus for the first few times (Dober, 1992; Strange \& Banning, 2000). Lynch also defined way finding and expressed its importance in urban design (Lynch, 1960). The identity of the open space is stressed by the use of landmarks. In open space, the absence of landmarks disorients the user and gives no identity to space, making it more difficult to remember the open space and to reuse it (Abu-Ghazzeh, 1999). 
Table 1: Factor analysis of social inclusion variables

\begin{tabular}{|c|c|c|}
\hline Survey Items & $\begin{array}{l}\text { Factor } \\
\text { Loadings }\end{array}$ & $\begin{array}{l}\text { Cronbach's } \\
\text { alpha }\end{array}$ \\
\hline Factor 1- Legibility & & .85 \\
\hline Easy to navigate around campus & .756 & \\
\hline Enough and clearly written signage & .743 & \\
\hline Well-defined and directional routes & .738 & \\
\hline Sufficient landmarks on campus & .725 & \\
\hline Easily recognizable buildings & .721 & \\
\hline Total variance & 27.07 & \\
\hline Factor 2- Social Relation & & .84 \\
\hline There are enough friends I feel close to. & .850 & \\
\hline Spend time with friends & .747 & \\
\hline Rely on friends when I have problems. & .742 & \\
\hline Academic discussion with students & .658 & \\
\hline $\begin{array}{l}\text { Have friendly relations with students of diverse } \\
\text { ethnicity. }\end{array}$ & .529 & \\
\hline Total variance & 7.80 & \\
\hline Factor 3- Hostel Quality & & .87 \\
\hline Comfortable living condition & .809 & \\
\hline Maintenance \& cleanliness & .760 & \\
\hline Quality and sufficiency of facilities & .756 & \\
\hline The hostel staffs are helpful. & .626 & \\
\hline Location & .601 & \\
\hline Total variance & 5.40 & \\
\hline Factor 4- Facilities & & .83 \\
\hline Stationary facilities & .713 & \\
\hline Food services & .615 & \\
\hline Sport and recreational facilities & .557 & \\
\hline Healthcare services & .556 & \\
\hline Total variance & 4.12 & \\
\hline Factor 5- Extracurricular activities & & .87 \\
\hline Perform volunteer activities. & .802 & \\
\hline Participate in residence activities. & .784 & \\
\hline Participate in religious activities. & .768 & \\
\hline Participate in recreational activities. & .703 & \\
\hline Total variance & 3.91 & \\
\hline Factor 6- Accessibility & & .87 \\
\hline Campus is pedestrian and cyclist friendly. & .754 & \\
\hline Easy access to facilities for all students & 679 & \\
\hline Proximity of destinations on campus & .595 & \\
\hline Total variance & 3.56 & \\
\hline Factor 7- Safety & & .82 \\
\hline Well-lit campus areas & .794 & \\
\hline Feel safe walking alone on campus. & .789 & \\
\hline Safety and security of residential halls & .693 & \\
\hline Availability of security guards & .653 & \\
\hline Total variance & 3.25 & \\
\hline Factor 8- Comfort & & .82 \\
\hline Campus is clean and well maintained. & .742 & \\
\hline
\end{tabular}




\begin{tabular}{|c|c|}
\hline Comfortable furniture in shaded locations & .679 \\
\hline Landscaping provides a pleasant visual experience & .639 \\
\hline Continuity of appropriate sidewalks & .581 \\
\hline Total variance & 2.80 \\
\hline Factor 9- Academic services & .85 \\
\hline The library and lab staff are helpful & .702 \\
\hline Adequate and up-to-date library resources & .694 \\
\hline Well-equipped classes \& labs & .640 \\
\hline Total variance & 2.50 \\
\hline Factor 10- Transportation & .83 \\
\hline Information about time schedule of bus & .745 \\
\hline Convenient location of bus stops & .717 \\
\hline Availability \& regularity of bus service & .694 \\
\hline Total variance & 2.11 \\
\hline
\end{tabular}

\subsection{Conclusion}

Regarding the diversity of the student population and the increased number of international students, there is an intensified need for insights on whether students are engaging effectively with the learning environment. This study aimed to identify the important factors predicting student inclusion with the campus environment in three public universities of Malaysia. The findings have theoretical contributions and practical implications where the framework serves as a tool for assisting university administrators to better understand students' needs and allocate resources effectively. In addition, this study helps designers and planners to create future campus environments that are conducive to students' academic and social integration.

As a limitation of the present study, this research was conducted in only three Malaysian universities; therefore, it is difficult to determine whether the same study at other institutions would generate similar results. Further research is needed to include both quantitative and qualitative methods. Hence, using focus group or individual interviews is strongly recommended.

\section{Acknowledgement}

The authors acknowledge the financial support provided by Research Management (RMC), Universiti Teknologi Malaysia, under grant vote number $01 \mathrm{~K} 10$, and Center of Built Environment in Malay World (KALAM), in addition to the research support from the Department of Landscape Architecture, Faculty of Built Environment, and Universiti Teknologi Malaysia.

\section{References}

Abd-Razak, M. Z., Abdullah, N. A. G., Nor, M. F. I. M., Usman, I. M. S., \& Che-Ani, A. I. (2011). Toward a Sustainable Campus: Comparison of the Physical Development Planning of Research University Campuses in Malaysia Journal of Sustainable Development, 4(4), 210-221. 
Abu-Ghazzeh, T. M. (1999). Communicating Behavioral Research to Campus Design. Environment and behavior, 31(6), 764-804.

Arambewela, R., \& Hall, J. (2009). An empirical model of international student satisfaction. Asia Pacific journal of marketing and logistics, 21(4), 555-569.

Arslan, S., \& Akkas, O. A. (2013). Quality of College Life (QCL) of Students in Turkey: Students' Life Satisfaction and Identification. Social Indicators Research, 1-16.

Astin, A. W. (1984). Student involvement: A developmental theory for higher education. Journal of college student personnel, 25(4), 297-308.

Astin, A.W. (1993). What matters in college? Four critical years revisited. San Francisco, CA: Jossey-Bass.

Atkinson, R. (2000). Combating social exclusion in Europe: the new urban policy challenge. Urban Studies, 37(5-6), 1037-1055.

Balyer, A., \& Gunduz, Y. (2012). Effects of structured extracurricular facilities on students' academic and social development. Procedia-Social and Behavioral Sciences, 46, 4803-4807.

Church, A., Frost, M., \& Sullivan, K. (2000). Transport and social exclusion in London. Transport Policy, 7(3), 195205.

Crosling, G., Thomas, L., and Heagney, M. (2008). Improving student retention in higher education: the role of teaching and learning: Routledge.

Dober, R. (1992). Campus Design. New York, NY: John Wiley \& Sons.

Douglas, J., Douglas, A., \& Barnes, B. (2006). Measuring student satisfaction at a UK university. Quality assurance in education, 14(3), 251-267.

Ghahramanpouri, A., Lamit, H., \& Sedaghatnia, S. (2013). Urban Social Sustainability Trends in Research Literature. Asian Social Science, 9(4), p185.

Ghahramanpouri, A., Abdullah, A. S., Sedaghatnia, S., \& Lamit, H. (2015). Urban Social Sustainability Contributing Factors in Kuala Lumpur Streets. Procedia-Social and Behavioral Sciences, 201, 368-376.

Gruber, T., Fuß, S., Voss, R., \& Gläser-Zikuda, M. (2010). Examining student satisfaction with higher education services: Using a new measurement tool. International Journal of Public Sector Management, 23(2), 105-123.

Hodgson, F., \& Turner, J. (2003). Participation not consumption: the need for new participatory practices to address transport and social exclusion. Transport Policy, 10(4), 265-272.

Jiewanto, A., Laurens, C., \& Nelloh, L. (2012). Influence of Service Quality, University Image, and Student Satisfaction toward WOM Intention: A Case Study on Universitas Pelita Harapan Surabaya. Procedia-Social and Behavioral Sciences, 40, 16-23.

Joseph, M., \& Joseph, B. (1997). Service quality in education: a student perspective. Quality assurance in education, $5(1), 15-21$.

Kahu, E. R., Stephens, C., Leach, L., \& Zepke, N. (2013). The engagement of mature distance students. Higher Education Research \& Development, 32(5), 791-804.

Kenyon, S. (2011). Transport and social exclusion: access to higher education in the UK policy context. Journal of Transport Geography, 19(4), 763-771.

60 
Levitas, R., Pantazis, C., Fahmy, E., Gordon, D., Lloyd, E., \& Patsios, D. (2007). The multi-dimensional analysis of social exclusion: Department of Sociology and School for Social Policy, Townsend Centre for the International Study of Poverty and Bristol Institute for Public Affairs, University of Bristol

Lynch, K. (1960). The image of the city (Vol. 11): MIT press.

Marcus, C. C., \& Francis, C. (1998). People places: Design guidelines for urban open space: Wiley.

Marti, C. N. (2008). Dimensions of student engagement in American community colleges: Using the Community College Student Report in research and practice. Community College Journal of Research and Practice, 33(1), 1 24.

Najib, N. U. M., Yusof, N. A., \& Sani, N. M. (2012). The Effects of Students' Socio-Physical Backgrounds onto Satisfaction with Student Housing Facilities. Procedia-Social and Behavioral Sciences, 62, 64-74.

Pallant, J. (2010). SPSS survival manual: A step by step guide to data analysis using SPSS: McGraw-Hill International.

Pascarella, E.T., \& Terenzini, P.T. (2005). How college affects students: A third decade of research, (Vol. 2). Indianapolis, IN: Jossey-Bass.

Petruzzellis, L., D'Uggento, A. M., \& Romanazzi, S. (2006). Student satisfaction and quality of service in Italian universities. Managing Service Quality, 16(4), 349-364.

Price, I., Matzdorf, F., Smith, L., \& Agahi, H. (2003). The impact of facilities on student choice of university. Facilities, 21(10), 212-222.

Robson, S. (2011). Internationalization: a transformative agenda for higher education? Teachers and teaching. 17(6), 619-630.

Room, G. 1995. Beyond the Threshold: The Measurements and Analysis of Social Exclusion. Bristol: The Policy Press.

Salama, A. M. (2011). Assessing Qatar University's Campus Outdoor Spaces: Design Intentions Versus Users' Reactions. Enhancing Building Performance, 139.

Scutella, R., and Wilkins, R. (2010). Measuring Social Exclusion in Australia: Assessing Existing Data Sources. Australian Economic Review. 43(4), 449-463.

Sedaghatnia, S., Lamit, H., Ghahramanpouri, A., \& Mohamad, S. B. (2013). An Evaluation of Residents' Quality of Life through Neighborhood Satisfaction in Malaysia. Environmental Management and Sustainable Development, 2(1), 114.

Silver, H. (1994). Social exclusion and social solidarity: Three paradigms. International Labour Review. 133(5-6), $531-578$.

Sirgy, M. J., Grzeskowiak, S., \& Rahtz, D. (2007). Quality of college life (QCL) of students: Developing and validating a measure of well-being. Social Indicators Research, 80(2), 343-360.

Strange, C. (2003). Dynamics of campus environments. Student services: A handbook for the profession, 4, 297316.

Strange, C. C., and Banning, J. H. (2000). Educating by design:creating campus learning environments that work (1st eds.) San Francisco: Jossey-Bass. 
Sepideh Sedaghatnia, S., et.al. / Asian Journal of Behavioural Studies (AjBeS), 3(12) Jul / Aug 2018 (p.53-62)

Tinto, V. (1993). Leaving college: rethinking the causes and cures of student attrition. (2nd ed.) Chicago; London: University of Chicago Press.

Weisman, J. (1981). Evaluating Architectural Legibility Way-Finding in the Built Environment. Environment and behavior, 13(2), 189-204.

Zhai, L. (2012). Validation of an instrument to measure community college student satisfaction. Community College Journal of Research and Practice, 36(1), 47-58. 